\section{MEIO SÉCULO DE GEOGRAFIA}

Com o lançamento do número 100, comemoramos 50 anos de publicação ininterrupta da Finisterra-Revista Portuguesa de Geografia, fundada em 1966, por Orlando Ribeiro, Suzanne Daveau e Ilídio do Amaral e editada pelo Centro de Estudos Geográficos (CEG) da Universidade de Lisboa. A Finisterra nasceu da necessidade de divulgar a investigação que ia sendo realizada, e também para possibilitar permutas com revistas de instituições estrangeiras, à época quase única maneira de saber o que se fazia "lá fora". No artigo de abertura, faz-se um balanço dos 50 anos da revista, mostrando as características e evolução no que diz respeito aos temas tratados, línguas, nacionalidade dos autores, características dos artigos, assim como as estratégias de internacionalização e disseminação, sempre presentes, agora mais fáceis devido à internet e à presença em numerosas bases de indexação.

Foram sobretudo geógrafos que, durante estes últimos 50 anos, escreveram para a revista. Optámos, neste número especial, por um critério diferente. Pedimos a "não-geógrafos" que dissertassem sobre um tema central da Geografia: o Espaço. Foi lançado o desafio a diversas personalidades das artes, das ciências e das letras, dando-lhes total liberdade na forma de expressão e no conteúdo. A resposta que tivemos excedeu as expectativas, sendo agora editadas as diferentes contribuições. Alguns dos autores são "amigos” de longa data, de modo que os convites não foram completamente aleatórios. De outros autores apenas conhecíamos a obra; mas de igual maneira acederam generosamente ao nosso apelo. A todos estamos muito gratos.

\section{HALF A CENTURY OF GEOGRAPHY}

The publication of the $100^{\text {th }}$ issue of Finisterra celebrates 50 years of uninterrupted publication of this Portuguese Journal of Geography that was founded by Orlando Ribeiro, Suzanne Daveau and Ilídio do Amaral in 1966. Finisterra was edited by the Centre of Geographical Studies (CEG) of the University of Lisbon. It was launched to meet the need to disseminate the research carried out in Portugal and also to promote exchanges with journals of foreign institutions, which, at the time was almost the only way to know what was being carried out abroad. In the opening article there is a 50-year balance of the journal, describing in detail the characteristics and evolution with regard to topics, languages, authors' nationalities, characteristics of the articles, as well as internationalisation and dissemination strategies, always an important issue, now made easier due to the internet and the inclusion in numerous indexation bases.

During these last 50 years the majority of the authors that wrote for the journal were geographers. We have opted for a different criterion for this special issue. We asked "nongeographers" to write about a central theme of geography: Space. The challenge of providing texts on this subject, with total freedom concerning the form of expression and content, was set to several personalities from the Arts, Sciences and Humanities. The response exceeded our expectations. Some of the authors are long-time "friends" therefore the invitations were not made completely at random. Other authors were known to us only through their work and, nonetheless, they generously responded to our appeal. We are very grateful to all of them. 
Começamos por dois textos mais directamente relacionados com Arte. Abrimos com um trabalho de Pedro Calapez, a quem a Finisterra muito deve. Em 2001, colaborou no número temático sobre "Paisagem", oferecendo então à Finisterra sete pinturas, que hoje fazem parte do espólio do CEG, e de entre as quais se escolheu a capa da revista com a esfera armilar em fundo azul. Para marcar o número 100, foi utilizada outra das suas imagens. Estamos também gratos pela generosidade com que nos tem ajudado a melhorar aspectos estéticos da Finisterra. Pela abrangência com que figurativamente aborda o espaço, Pedro Calapez abre caminhos interpretativos para os textos seguintes. Vem depois uma contribuição de Duarte Belo, com o título “Tinta e Pó. Fotografias em Viagem”. As imagens que completam o texto transmitem uma visão de paisagens portuguesas, ao mesmo tempo plenas e despojadas. O seu encanto estará nessa aparente contradição.

Seguem-se textos sobre os mais diversos tipos de espaço, reais e fictícios, conhecidos ou não. Victor Gonçalves escreve sobre espaços inventados, dando sobre eles interessantes e inesperados exemplos. Parte do mundo imaginário e sem fronteiras da boa literatura de ficção científica para a necessidade de interpretação espacial e cartográfica desses espaços fictícios. Henrique Garcia Pereira discute a categoria filosófica de espaço, o seu impacte em diferentes ciências, bem como o seu significado nas artes e na literatura, passando em revista os grandes pensadores da interpretação espacial. António e André Nóvoa reflectem sobre o espaço visível e invisível, conhecido e desconhecido. Fazem, de certo modo, um zoom (também temporal) entre espaços infinitos, espaços delimitados por proximidades e distâncias e o espaço-tempo na perspectiva relacional.
We begin with two texts directly related to Art. The first one was written by Pedro Calapez to whom Finisterra is very indebted. In 2001, he collaborated in the thematic issue on "Paisagem" (Landscape) and offered seven paintings to Finisterra, which are now part of the estate of CEG. One of the paintings, with the armillary sphere on blue background, was then chosen for the journal's cover page. Another of his paintings was selected to celebrate the $100^{\text {th }}$ issue of Finisterra. We are also grateful for his generosity in helping us to improve the aesthetic aspects of Finisterra. The extent to which Pedro Calapez figuratively address space opens up interpretive paths for the following texts. A contribution by Duarte Belo, titled "Paint and Powder. Photos trip" follows. The images that complement the text convey a vision of Portuguese landscapes, which are at the same time full and uncluttered. Its charm lies in this apparent contradiction.

Next we find texts about the various types of space, real and fictional, known or unknown. Victor Gonçalves writes about invented spaces providing interesting and unexpected examples. He starts with the imaginary and boundless world of good science fiction literature and reaches the need for spatial interpretation and mapping of these fictitious spaces. Henrique Garcia Pereira discusses the philosophical category of space, its impact in different sciences as well as its meaning in the arts and in literature and reviews the works of great thinkers of spatial interpretation. António and André Nóvoa reflect on the visible and invisible, known and unknown space. In a way they 'zoom' (in space as well as in time) between infinite spaces, spaces delimited by proximity and distance and space-time in a relational perspective. 
Partimos depois para o "espaço" (no sentido de Universo) e para a atmosfera. Teresa Lago chama a atenção para um espaço físico muito concreto, caracterizado pelas enormes distâncias entre corpos celestes, e reflecte sobre o modo como as novas tecnologias têm enriquecido o conhecimento da nossa galáxia. João Corte-Real discute os fundamentos da previsão do tempo num espaço específico - a atmosfera - e as vantagens daí decorrentes para a prevenção de desastres de origem meteorológica.

Os dois textos seguintes completam-se, na medida em que José Reis objectiva a deambulação ética e filosófica acerca das políticas e dos direitos abordados por Porfírio Silva. José Reis revisita "dois mundos: o da interpretação e do conhecimento do território e o das formas de lidar com ele através das políticas públicas". Porfírio Silva, para responder à interrogação de quem é o espaço entre instituições, refere a dicotomia entre espaço objectivo e subjectivo e introduz a teoria do actor-rede. Conclui que o espaço é uma construção cooperativa entre a natureza e os agentes em sociedade, entre os quais as instituições.

O binómio espaço-tempo em Portugal leva os nossos convidados a reflexões diversas. Marcelo Rebelo de Sousa sintetiza em poucas frases dilemas dessa relação no "Espaço Portugal”. Filomena Silvano discute a evolução da noção de lugar e a desterritorialização (que surpreendentemente pode contribuir para a reconstrução do "lugar"), a partir de um estudo etnográfico na ilha do Pico nos Açores. Faz uma interpretação da hibridação local-global a partir da relação desse Portugal insular com os EUA. Maria do Carmo Piçarra traz-nos uma narrativa do poder exercido pela nação portuguesa no "Ultramar", a partir da filmografia documentarista do Estado Novo. É comentado um filme realizado numa expedição às "coló-
"Space" (in the sense of Universe) and the atmosphere come next. Teresa Lago draws attention to a very specific physical space characterised by huge distances between celestial bodies and points out how new technologies have enriched the knowledge of our galaxy. João Corte Real discusses the basics of weather forecasting in a specific space - the atmosphere -and the resulting advantages for the prevention of weather-induced disasters.

The two following texts complement each other as José Reis addresses in an objective fashion the ethics and philosophical discourse of Porfírio Silva on politics and rights. José Reis revisits "two worlds: the interpretation and knowledge of the territory and the way to deal with it through public policies". In order to answer the question of who owns the space between institutions, Porfirio Silva refers the dichotomy between objective and subjective space and explains the 'actor-network' theory. The Author concludes that space is a cooperative construction between nature and the agents in society, namely the institutions.

The relationship between space and time in Portugal, leads our guests to different reflexions. Marcelo Rebelo de Sousa sums up in a few sentences the dilemmas of that relationship in the "Space-Portugal". Filomena Silvano discusses the evolution of the concept of place and deterritorialisation (which oddly can contribute to the reconstruction of the "place") from an ethnographic study on the island of Pico in the Azores. She provides an interpretation of the local-global hybridisation based on the relationship of insular Portugal with the U.S. M. do Carmo Piçarra comments on the power exerted by Portugal in the overseas colonies, based on the filmed documentaries of the "Estado Novo" (New State). She comments on a film made during an expedition to 
nias" em 1935, uma "paisagem sem homens", onde Orlando Ribeiro, como participante, introduziu a compaixão do investigador por esse mundo então quase desconhecido. Alexandra Lucas Coelho fala-nos de "A serra", que Orlando Ribeiro lhe ajudou a descobrir como uma comunidade e transpirando poesia. Tal como Duarte Belo, que escreve numa prosa poética, também Alexandra Lucas Coelho, como Maria do Carmo Piçarra, evoca o humanismo tocante de Orlando Ribeiro.

Afinal, nestes textos de convidados não geógrafos, revisitam-se e reconstroem-se alguns dos conceitos centrais em Geografia.

A partir do próximo número deixarei de ser Directora da Finisterra, cargo que detenho desde 2000. Durante estes 15 anos, dediquei-me à revista com empenho e entusiasmo, coadjuvada por colegas que constituíram os diversos "Secretariados", "Comissões de Redacção" ou, ultimamente "Comissões Executivas" (CE), cujos nomes constam no primeiro artigo deste volume. Cada um, com a sua personalidade e interesses diversos, contribuiu para um eficaz trabalho de grupo, permitindo ir enfrentando as habituais vicissitudes da edição de uma revista científica e concorrendo para a sua progressiva modernização. Foram anos de partilha, de discussões construtivas, de busca de soluções, de novas ideias para a revista e... de muito trabalho. Apostou-se na normalização de procedimentos, na internacionalização e na difusão em acesso aberto. A obra feita está descrita no primeiro artigo deste número 100 da Finisterra e cada um poderá julgar por si.

Da Comissão Executiva que agora termina funções, foi com Margarida Queirós que trabalhei mais tempo (desde 1999). Partilhá- the "colonies" in 1935, a "landscape without men", in which Orlando Ribeiro, as a participant, conveys the compassion of the researcher for what was then a nearly unknown world. Alexandra Lucas Coelho in a poetic text speaks of the Serra" (Estrela Mountain) that Orlando Ribeiro helped her to discover as a community. Like Duarte Belo, who writes in a poetic prose, A. Lucas Coelho and M. do Carmo Piçarra evoke the touching humanism of Orlando Ribeiro.

After all, some of the central concepts in geography are rethought and rebuilt in the texts written by our non-geographer guests.

After the current issue I will cease to be Director of Finisterra, a position I have held since 2000. During these 15 years, I have devoted myself to the journal with commitment and enthusiasm. I was assisted by several colleagues who worked in the various "Bureaus", "Drafting Committees" and lately in "Executive Committees" (EC); their names appear in the first article of this volume. Each one of them, with his/her own personality and interests, contributed to an effective team work, facing the usual vicissitudes of editing a scientific journal. Those were years of sharing, of constructive discussions, search for solutions and new ideas for the journal ... and a lot of work! The results we achieved are described in the first paper of this issue and readers can judge for themselves.

The person I have worked with the longest (since 1999) is Margarida Queirós of the Executive Committee. We shared challenges and concerns, but also the pleasure of seeing results such as the uninterrupted publication of Finisterra and its gradual inte- 
mos desafios, tarefas árduas e preocupações, mas também o prazer de ver resultados como a publicação ininterrupta da Finisterra e a sua progressiva integração listas de indexação. Além disso, partilhámos com as equipas então em funções, a organização de dois colóquios, a que corresponderam números temáticos da revista, um sobre "Paisagem" (em 2002) e um outro relativo a Sistemas de Informação Geográfica (em 2005). Nos últimos anos M. Fernanda Alegria voltou à Finisterra e a sua inestimável experiência, trabalho árduo e espírito crítico foram uma enorme mais-valia, numa altura em que os jovens colegas estavam assoberbados por tarefas lectivas, administrativas e de investigação. Paulo Morgado, membro activo da CE desde 2001 e nosso editor cartográfico e Ricardo Garcia, recentemente integrado na CE, tiveram papel importante em vários campos, incluindo a gestão do Repositório Científico de Acesso Aberto de Portugal (RCAAP). A Directora e a CE passaram a ser, desde 2010, assistidas por Rute Vieira, a muito diligente, dedicada e eficiente Secretária da Finisterra, cuja lista de tarefas é extensíssima. Refira-se também o papel das diversas Comissões editoriais (internas e externas, nacionais e internacionais), dos editores de Secção e dos revisores anónimos, cujos nomes se publicam de dois em dois anos, a quem muito devemos.

Uma revista é editada por Pessoas que, em conjunto, fazem "andar o barco", por vezes em detrimento do seu trabalho profissional ou da sua vida pessoal. A todas devo um agradecimento especial (incluindo, claro, todos os elementos das "Comissões" anteriores, com quem trabalhei, e que não citei individualmente para não alongar demasiado esta nota). Dirijo palavras de apreço à Professora Suzanne Daveau e ao Professor Ilídio do Amaral que, conjuntamente com o Professor Orlando Ribeiro, fundaram e dirigiram a revista e que gration into indexation platforms. In addition, we shared with the teams in office at the time the organisation of two colloquiums that led to the publication of thematic issues, one about "Landscape" (in 2002) and another one on "Geographical Information Systems" (GIS, in 2005). In recent years, M. Fernanda Alegria returned to Finisterra and her invaluable experience, hard work and critical mind have been a huge asset. Paulo Morgado, EC member since 2001 and our cartographic editor, and Ricardo Garcia recently integrated in the EC, had important roles in numerous fields, including the management of the Open-Access Scientific Repository of Portugal (RCAAP). Since 2010, we have been assisted by Rute Vieira, the very diligent, dedicated and efficient Secretary of Finisterra, whose to-do list is a mile long! It is worth noting the role of the various editorial Committees (internal and external, national and international), of Section editors and of the anonymous reviewers whose names are listed every two years and to whom we owe so much.

A journal is edited by people who, together, make things happen sometimes to the detriment of their professional and personal life. I owe all of them a special thank you (including, of course, all the elements of the "Commissions" I have worked with in previous years). I owe a word of thanks to Professor Suzanne Daveau and Professor Ilídio do Amaral who, together with Professor Orlando Ribeiro, founded the Journal. I wish to thank Professor Jorge Gaspar for insisting with me to accept the post of secretary of Finisterra in 1992 and for his participation in the Journal's life over the years. To Professor Carlos Alberto Medeiros, who preceded me as the director of Finisterra and with whom I learned so much, I also owe the 
sempre me apoiaram. Ao Professor Jorge Gaspar, agradeço o convite para o cargo de secretária da Finisterra em 1992 e o seu interesse participativo na vida da revista. Ao Professor Carlos Alberto Medeiros, que me precedeu na Direcção e com quem aprendi muitíssimo, devo a também sugestão do meu nome ao Conselho Científico do CEG para a Direcção da Finisterra, no ano 2000. Estou igualmente grata aos órgãos dirigentes do CEG e do Instituto de Geografia e Ordenamento do Território e a numerosos Colegas e Funcionários que, ao longo dos anos, apoiaram a Finisterra. Aos Autores e Leitores, que são a nossa razão de ser, obrigada pela confiança e interesse na revista.

Muito foi feito, muito está ainda por fazer. Considero que a nova Directora, Margarida Queirós, tem qualidades comprovadas de trabalho e de inteligência para a liderança da revista, ideias interessantes para a sua renovação e determinação para executar o seu programa. Além disso, reuniu uma equipa de promissores e entusiastas jovens geógrafos que, em conjunto, conduzirão seguramente a Finisterra por caminhos acertados e inovadores. Desejo a Margarida Queirós as maiores felicidades na Direcção da Finisterra. suggestion of my name as his successor to the Scientific Council of the CEG in 2000. I am also indebted to the Directions of the CEG and of the Institute of Geography and Spatial Planning as well as to many Colleagues and Co-Workers who have supported Finisterra over the years by backing up its Director and the successive Committees. To the authors and the readers, who are the ultimate reason for the publication of a Journal, thank you for your trust and confidence.

Much has been achieved but much still remains to be done. I believe that the new director, Margarida Queirós, has proven qualities of intelligence and hard work to lead the journal. She has interesting ideas for renewal and the determination to implement her program. Furthermore, she has assembled a team of promising and enthusiastic young geographers who will surely help her to lead Finisterra through suitable and innovative paths. I would like to wish Margarida Queirós every success in the direction of Finisterra. 